\title{
The eastern industrial zone in Ethiopia: catalyst for development?
}

\author{
Philip Giannecchini and Ian Taylor
}

\begin{tabular}{|l|l|}
\hline Date of deposit & 06122017 \\
\hline Document version & Author's accepted manuscript \\
\hline Access rights & $\begin{array}{l}\text { C } 2017 \text { Elsevier Ltd. This work is made available online in } \\
\text { accordance with the publisher's policies. This is the author } \\
\text { created, accepted version manuscript following peer review and } \\
\text { may differ slightly from the final published version. }\end{array}$ \\
\hline $\begin{array}{l}\text { Citation for } \\
\text { published version }\end{array}$ & $\begin{array}{l}\text { Giannecchini, P., and Taylor, I. (2017). The eastern industrial } \\
\text { zone in Ethiopia: catalyst for development? Geoforum, 88: pp. } \\
\text { 28-35. }\end{array}$ \\
\hline $\begin{array}{l}\text { Link to published } \\
\text { version }\end{array}$ & https://doi.org/10.1016/j.geoforum.2017.11.003 \\
\hline
\end{tabular}

Full metadata for this item is available in St Andrews Research

Repository at: https://research-repository.st-andrews.ac.uk/

\section{St Andrews Research Repository}




\section{THE EASTERN INDUSTRIAL ZONE IN ETHIOPIA: CATALYST FOR DEVELOPMENT?}

In 2000, at the Forum on China-Africa Cooperation (FOCAC) meeting in Beijing, the Programme for China-Africa Cooperation in Economic and Social Development was launched, in which China agreed to share with African countries its experience in the field of investment promotion relating to the establishment and management of special economic zones (SEZs). ${ }^{1}$ Since then, two competitive tenders have led to proposals for the development of seven SEZs in six African countries being approved by the Chinese Ministry of Commerce (MOFCOM), including one in Ethiopia: the Eastern Industrial Zone, located in Oromia region around Dukem, a small town some $35 \mathrm{~km}$ south-east of Addis Ababa. ${ }^{2} \mathrm{Of}$ the seven proposed zones, Ethiopia's represents one of the biggest challenges to both the Chinese developers and the host government alike. ${ }^{3}$ Due to its geographical location and the absence of any serious SEZ experience in Ethiopia, the zone's ability to contribute to Ethiopia's economic development remains unclear. Both the Chinese and Ethiopian sides however appear very keen for the zone to work: in May 2014, Chinese Premier Li Keqiang visited the Zone, accompanied by the Prime Minister of Ethiopia, Hailemariam Desalegn. Ethiopia in fact is emerging as a veritable hive of economic zones and industrial parks. In 2014 the Ethiopian Industrial Parks Development Corporation (IPDC) was established. Currently, in Ethiopia there are four industrial zones (three of which are foreign-owned): the Eastern Industrial Zone; the Lebu Industrial Zone, owned by Huajian Group; Modjo Industrial Zone owned by George Shoe and the Bole Lemi Industrial Zone, owned by the Ethiopian state. In 2015,

\footnotetext{
${ }^{1}$ See Ian Taylor The Forum on China-Africa Cooperation (FOCAC) London: Routledge, 2011.

${ }^{2}$ The others are located in Algeria (the Algeria-China Jiangling Free Trade Zone); Egypt (the China-Egypt Suez Economic and Trade Cooperation Zone); Mauritius (the Mauritius Jinfei Economic Trade and Cooperation Zone); two in Nigeria (the Lekki Free Trade Zone, and the Ogun/Chinese Free Trade Zone); and Zambia (the Zambia-China Economic and Trade Cooperation Zone in Chambishi, with a Lusaka sub-zone). The zones in Egypt and Zambia are already operating (the latter at a low-level capacity). Due to the restructuring of the investment policy in Algeria, zone development there has stalled.

${ }^{3}$ It should be added that in addition to the seven official zones, Chinese companies and provincial governments have established, on their own initiative, zones in Botswana (China Daheng Textile Industrial Park); Guinea (Linyi Industrial Park), Nigeria (Lishi-CSI Industrial Park); and South Africa (Shandong Xinguang Textile Industrial Park). Some of these zones (the ones in Nigeria and Sierra Leone, for instance) originate from rejected proposals to MOFCOM during the tendering rounds.
} 
construction began on a \$246 million park dubbed Hawassa Industrial Park after the signing of an agreement between Addis and China Civil Engineering Corporation (CCECC). Hawassa Industrial Park, when finished, is planned to include 35 factory sheds and 19 buildings. The first phase will cover 100 hectares, while the remaining phase will add 200 hectares. ${ }^{4}$ Starting from 2016, IPDC will develop additional parks in Mekelle, Dire Dawa, Kombolcha, and probably also Adama. At the same time, feasibility studies will be conducted for Bahir Dar in the north-west and Jimma in the west. With a final size ranging from 500 to 2000 hectares, each park will be developed in phases of 75-200 hectares. ${ }^{5}$ Unlike the EIZ, these parks are targeted and coherent vis-à-vis industrial focus:

Industrial parks operated or owned by IPDC (Industrial Parks Development Corporation, 2015)

\begin{tabular}{|l|l|l|l|l|l|l|}
\hline & Site & $\begin{array}{l}\text { Delimited } \\
\text { land (ha) }\end{array}$ & $\begin{array}{l}\text { Phase } \\
\text { I }\end{array}$ & $\begin{array}{l}\text { Eligible } \\
\text { industries }\end{array}$ & $\begin{array}{l}\text { Completion } \\
\text { period of } \\
\text { Phase I }\end{array}$ & Status \\
\hline $\begin{array}{l}\text { Addis } \\
\text { Industry } \\
\text { Village }\end{array}$ & $\begin{array}{l}\text { Addis } \\
\text { Ababa }\end{array}$ & 8.7 & 8.7 & Apparel & 2012 & Operational \\
\hline $\begin{array}{l}\text { Bole Lemi } \\
\text { I }\end{array}$ & $\begin{array}{l}\text { Addis } \\
\text { Ababa }\end{array}$ & 156 & 156 & Apparel & 2014 & Operational \\
\hline $\begin{array}{l}\text { Bole Lemi } \\
\text { II }\end{array}$ & $\begin{array}{l}\text { Addis } \\
\text { Ababa }\end{array}$ & 186 & 186 & $\begin{array}{l}\text { Textiles and } \\
\text { apparel }\end{array}$ & 2017 & $\begin{array}{l}\text { Detail design } \\
\text { phase }\end{array}$ \\
\hline Kilinto & $\begin{array}{l}\text { Addis } \\
\text { Ababa }\end{array}$ & 337 & 337 & $\begin{array}{l}\text { Food } \\
\text { processing, } \\
\text { pharmaceuticals, } \\
\text { furniture, } \\
\text { household } \\
\text { appliances, }\end{array}$ & 2017 & Detail design \\
phase
\end{tabular}

\footnotetext{
${ }^{4}$ Government of Ethiopia 'Ethiopia: Hawassa Industrial Park to Be Constructed', July 20, 2015.

${ }^{5}$ Industrial Parks Development Corporation, http://www.ipdc.gov.et
} 


\begin{tabular}{|c|c|c|c|c|c|c|}
\hline & & & & $\begin{array}{ll}\text { electronic and } \\
\text { electrical }\end{array}$ & & \\
\hline Hawassa & South & 300 & 100 & $\begin{array}{l}\text { Textiles and } \\
\text { apparel }\end{array}$ & 2016 & $\begin{array}{l}\text { Under } \\
\text { construction }\end{array}$ \\
\hline Dire Dawa & East & 1500 & 150 & $\begin{array}{l}\text { Textiles and } \\
\text { apparel, vehicles } \\
\text { assembly, food } \\
\text { processing }\end{array}$ & 2016 & $\begin{array}{l}\text { Under } \\
\text { construction }\end{array}$ \\
\hline Kombolcha & $\begin{array}{l}\text { North- } \\
\text { east }\end{array}$ & 700 & 50 & $\begin{array}{lr}\text { Textiles } & \text { and } \\
\text { apparel, } & \text { food } \\
\text { processing } & \end{array}$ & 2016 & Open for bids \\
\hline Mekelle & North & 1000 & 50 & $\begin{array}{lr}\text { Textiles and } \\
\text { apparel, food } \\
\text { processing }\end{array}$ & 2016 & Open for bids \\
\hline Adama & $\begin{array}{l}\text { South- } \\
\text { east }\end{array}$ & 2000 & 100 & $\begin{array}{l}\text { Textiles and } \\
\text { apparel, vehicles } \\
\text { assembly, food } \\
\text { processing }\end{array}$ & 2016 & $\begin{array}{l}\text { Feasibility study } \\
\text { phase }\end{array}$ \\
\hline Bahir Dar & $\begin{array}{l}\text { North- } \\
\text { west }\end{array}$ & 1000 & 50 & $\begin{array}{lr}\text { Textiles } & \text { and } \\
\text { apparel, food } \\
\text { processing }\end{array}$ & $2016 / 2017$ & $\begin{array}{l}\text { Feasibility study } \\
\text { phase }\end{array}$ \\
\hline Jimma & $\begin{array}{l}\text { South- } \\
\text { west }\end{array}$ & 500 & 50 & $\begin{array}{lr}\text { Textiles } & \text { and } \\
\text { apparel, } & \text { food } \\
\text { processing } & \end{array}$ & $2016 / 2017$ & $\begin{array}{l}\text { Feasibility study } \\
\text { phase }\end{array}$ \\
\hline
\end{tabular}

Constructed at the interface between the top-down and the bottom-up, industrial parks and SEZs have very real implications for people living in or near the spaces where they are constructed. Concrete studies of the SEZs in action is the most fruitful avenue in lifting the veil of obscurity over much of what is really occurring "on the ground" vis-à-vis these projects. This is not least because both Beijing and the various host African governments have marketed the "SEZ model" as the basis for future deepened collaboration between China and the continent. Indicative of this 
commitment was a major conference held in Beijing in December 2015 entitled "Industrial Parks and Globalization: Experience Sharing between China and Africa”, which sought to discuss best practices and past experiences. The success or otherwise of existing Chinese SEZs in Africa, and the processes engendered by the various projects are thus of crucial importance for discussions around African development and the role that China may or may not play. ${ }^{6}$

This article is based on primary research involving interviews with investors, zone developers and operators, regulatory authorities, government officials, and other key stakeholders which were conducted in both Beijing and Ethiopia. The study integrates investigations into the agenda-setting behaviours of both Ethiopian and Chinese actors involved in the Eastern Industrial Zone initiatives, identifying who decides what and with what means, and for whom, for what purpose and with what consequences. Analysis of the zones' potential to have an effect on development in Ethiopia, the current obstacles faced and the potential benefits for all the relevant stakeholders are outlined. The article takes as its starting point previous accounts of the Eastern Industrial Zone, ${ }^{7}$ as well as a recent study of Ethiopia's industrial policy, which utilises the theories associated with the economist, Albert O. Hirschman. ${ }^{8}$

Fundamentally, this article seeks to analyse the progress thus far in the Ethiopian SEZ, to identify the strengths and weaknesses of the project and to determine what impact, if any, the development of this zone will have on Ethiopia's structural transformation. This last point is important given that the SEZ scheme is a central component of FOCAC and is heralded as a concrete way in which Beijing is exporting its "model" of development to Africa for economic change. More concretely, the Ethiopian government has decided that the Eastern Industrial Zone (EIZ) is an integral part of its Sustainable Development and Poverty Reduction Program (SDPRP)

\footnotetext{
${ }^{6}$ See Deborah Brautigam and Tang Xiayang 'African Shenzhen: China's Special Economic Zones in Africa', Journal of Modern African Studies, 49, 1 (2011), pp. 27-54.

${ }^{7}$ Deborah Brautigam and Xiaoyang Tang 'China's Investment in Africa's Special Economic Zones' in Thomas Farole and Gokhan Akinci (eds.) Special Economic Zones: Progress, Emerging Challenges, and Future Directions Washington, DC: World Bank, 2011; Deborah Brautigam and Xiaoyang Tang "Going Global in Groups": Structural Transformation and China's Special Economic Zones Overseas', World Development, vol. 63, 2014, pp. 78-91.

${ }^{8}$ Arkebe Oqubay Made in Africa: Industrial Policy in Ethiopia Oxford: Oxford University Press, 2015.
} 
and the key element in its industrial development ambitions. ${ }^{9}$ As the article will detail, the zone's contribution to structural transformation of the Ethiopian economy is vital if the zone is to have a catalytic effect on sustainable development in Ethiopia. Structural change is here taken as an increase in the share of industry or services in the economy, or as the broadening and sophistication of exports or as the move of workers from low labour productivity sectors to those with high labour productivity. ${ }^{10}$

\section{Special Economic Zones}

Special Economic Zones can be understood as a blanket term used to describe a variety of economic initiatives including, but not limited to, Free Trade Zones (FTZs), Export Processing Zones (EPZs), Industrial Zones and Free Ports. ${ }^{11}$ SEZs are best understood as spatially defined geographic areas designed to attract foreign investment by providing economic and commercial policies that are more liberal than in the rest of the country, along with infrastructure investment designed to facilitate streamlined operations and lower transaction costs for investors. In China's case, "bringing in" (yin jinlai) foreign direct investment, technology and skills was central to the SEZ methodology as practiced post-Mao. ${ }^{12}$

As a rule, SEZs are long-term orientated, usually taking over a decade to mature, and are evolutionary and flexible by nature: as an SEZ develops, its objectives and priorities invariably change. A usual evolution is characterised by a shift in focus from attracting foreign direct investment (FDI) to technology-upgrading, with a strong focus on encouraging domestic private investment. The methods employed to achieve these objectives-including incentives and

${ }^{9}$ Sustainable Development and Poverty Reduction Program Addis Ababa: Federal Democratic Republic of Ethiopia, 2002. See also Growth and Transformation Plan, 2010/11-2014/15 Addis Ababa: Ministry of Finance and Economic Development, 2010.

10 Alice Sindzingre 'The Ambivalent Impact of Commodities: Structural Change or Status Quo in Sub-Saharan Africa?', South African Journal of International Affairs, vol. 20, no. 1, 2013, p. 26.

${ }^{11}$ Susan Tiefenbrun Tax Free Trade Zones of the World and in the United States Cheltenham: Edward Elgar, 2012.

${ }^{12}$ See Gao Shangquan and Chi Fulin New Progress in China's Special Economic Zones Beijing: Foreign Languages Press, 1997; Jung-Dong Park The Special Economic Zones of China and Their Impact on Its Economic Development Westport, CT: Greenwood Press, 1997; and Douglas Zhihua Zheng Building Engines for Growth and Competitiveness in China: Experience with Special Economic Zones and Industrial Clusters Washington DC: World Bank Publications, 2010. 
policies - are adjusted where and when necessary to meet the changing needs of investors, the host government, and the wider context of the global economic environment. ${ }^{13}$

Utilised effectively, successes are popularized and up-scaled whilst failures are discarded and lessons are learned. In short, as an ideal type, SEZs represent a kind of testing ground, an incubator of ideas and policies designed and implemented to take advantage of comparative advantages in host economies. ${ }^{14}$ However, it is not uncommon for SEZs to fail to reach maturity or to have the desired catalytic impacts that the SEZ prospectuses promise. ${ }^{15}$ Studying concrete examples of actual SEZs is thus vital if their actual, rather than claimed, efficacy is to be evaluated competently.

In Africa, the first official export processing zones (EPZs) were established in Mauritius in $1971 .{ }^{16}$ Today, over twenty African countries have played host to various industrial clusters, be they EPZs, SEZs, FTZs or spatial industrial parks. Problematically-and for reasons that echo much of the situation in the Ethiopian SEZ example (see below) - the broad results of SEZs in Africa have been uninspiring. Incompletion of the projects, partial functioning and, in some cases, termination of the project itself, has been the history of SEZs across the continent. It is for these reasons that a preliminary study and assessment of the Ethiopian SEZ is pertinent.

\section{The Eastern Industrial Zone - Overview and Objectives}

The Eastern Industrial Zone in Ethiopia was initially planned in 2007 and launched in 2009 by the Ethiopian minister of trade and industry and the Chinese ambassador to Ethiopia. Located in Dukem, Oromia state, around 30 kilometres south-east of the capital, Addis Ababa, the original plan was to establish a $5 \mathrm{~km}^{2}$ zone operated by the Yonggang Group and the Qiyuan Group, which in five years would entice eighty separate investment projects, creating 20,000 jobs. ${ }^{17}$ However,

\footnotetext{
${ }^{13}$ Wei Ge Special Economic Zones and the Economic Transition in China Hackensack, NJ: World Scientific Publishing, 1999.

${ }^{14}$ Connie Carter and Andrew Harding (eds.) Special Economic Zones in Asian Market Economies London: Routledge, 2010.

${ }^{15}$ See Amitendu Palit and Subhomoy Bhattacharjee Special Economic Zones in India: Myths and Realities New Delhi: Anthem Press, 2008.

${ }^{16}$ For an excellent overview of the African experience of SEZs, see Thomas Farole Special Economic Zones in Africa: Comparing Performance and Learning from Global Experiences Washington DC: World Bank, 2011.

${ }^{17}$ Brautigam, 2011.
} 
the Yonggang Group soon abandoned the project and the zone currently consists of an area of $2 \mathrm{~km}^{2}$, a downsizing of over $50 \% .{ }^{18}$ Like most other Chinese SEZs in Africa, the Ethiopian zone is 100\% Chinese-owned, developed and operated by the aforementioned Qiyuan Group, a Chinabased privately owned steel manufacturer. In addition to the provision of land at an extremely favourable rate - one Ethiopian birr (around \$0.05) per square meter/per year for 99 years — the Ethiopian government has also agreed to provide all the necessary infrastructure outside the zone and to cover the cost of $30 \%$ of the internal infrastructure. ${ }^{19}$ This is a remarkable commitment from Addis Ababa and hints at the focus within Ethiopia to promote industrialisation. ${ }^{20}$ The previous prime minister, Meles Zenawi, was a strong proponent of industrialisation and looked to the Asian late developers for inspiration. ${ }^{21}$ It was under him that the details of the EIZ were agreed upon and, starting under Meles' leadership, Ethiopia embarked upon a remarkable capital spending programme on large investments (around 15 per cent of GDP) in infrastructure projects. Railways, roads and dam projects have all been part of this endeavour, as has the industrial parks. This huge public investment is credited with driving economic growth above 10 percent. However, the state has borne the brunt of raising financing, whilst at the same time requiring that banks invest the equivalent of 27 percent of the loan portfolio in low-yield state development bonds. Whilst this has been an integral part of the country's development strategy, the World Bank has criticised Addis for reducing the ability of private businesses to borrow. ${ }^{22}$

Returning to the EIZ, the focus of the Eastern Zone is difficult to ascertain and contrasts with the projects being advanced by the IPDC. The EIZ started out focusing on the production of

\footnotetext{
${ }^{18}$ Interview with Ministry of Industry official, Addis Ababa, January 2011.

${ }^{19}$ Interview with Hagos Sequar, Project Promotion Department Manager of the Eastern Industrial Zone, Addis Ababa, January 2011.

${ }^{20}$ Interview with Dessalegn Rahmato, Researcher and Private Consultant, Addis Ababa, September 3, 2013.

${ }^{21}$ See Meles Zenawi African Development: Dead Ends and New Beginnings, unpublished Masters dissertation Rotterdam: Erasmus University, no date. Meles argued for an Ethiopian developmental state - see Meles Zenawi 'States and Markets: Neoliberal Limitations and the Case for a Developmental State' in Akbar Noman, Kwesi Botchwey, Howard Stein, and Joseph Stiglitz (eds.) Good Growth and Governance in Africa: Rethinking Development Strategies Oxford: Oxford University Press, 2012. For a discussion of Meles' legacy, see Alex de Waal 'The Theory and Practice of Meles Zenawi', African Affairs, 112 (446), 2013 and René Lefort 'The Theory and Practice of Meles Zenawi: A Response to Alex de Waal', African Affairs, 112 (448), 2013.

22 'World Bank says Ethiopia Should Diversify Infrastructure Funding', Reuters (Addis Ababa), November 24, 2015.
} 
construction materials as well as light industries, including the production of pharmaceuticals, electronics, chemicals and leather. ${ }^{23}$ However, this has now widely diversified. An indicative list of companies with a physical location in the zone is below:

${ }^{23}$ Interview with Chinese manager, Qiyuan Group, Eastern Industrial Zone, February 2011. 


\begin{tabular}{|c|c|c|c|c|}
\hline $\begin{array}{l}\text { Name of } \\
\text { company }\end{array}$ & \begin{tabular}{|l|} 
Date entered \\
zone
\end{tabular} & Investment & $\begin{array}{l}\text { Physical } \\
\text { presence }\end{array}$ & Industry \\
\hline $\begin{array}{l}\text { East Cement } \\
\text { Share Company }\end{array}$ & 2006 & $\$ 60$ million & N/A & $\begin{array}{l}\text { Cement } \\
\text { production }\end{array}$ \\
\hline Eastern Hotel & 2008 & $\$ 500,000$ & $3600 \mathrm{~m}^{2}$ hotel & Hotel \\
\hline $\begin{array}{l}\text { East Cement } \\
\text { Leasing } \\
\text { Company }\end{array}$ & 2008 & $\$ 5$ million & $\begin{array}{l}\text { Large } \\
\text { storage/parking } \\
\text { area }\end{array}$ & $\begin{array}{l}\text { Construction } \\
\text { equipment rental } \\
\text { services }\end{array}$ \\
\hline $\begin{array}{l}\text { Zhongshun } \\
\text { Cement } \\
\text { Manufacturing }\end{array}$ & 2008 & \$11 million & $30,750 \mathrm{~m} 2$ plant & $\begin{array}{l}\text { Cement } \\
\text { production }\end{array}$ \\
\hline $\begin{array}{l}\text { Chang Cheng } \\
\text { Packaging }\end{array}$ & 2010 & $\$ 510,000$ & $5000 \mathrm{~m}^{2}$ factory & $\begin{array}{l}\text { Packaging } \\
\text { materials }\end{array}$ \\
\hline $\begin{array}{lcc}\text { L } \quad \& \quad J \\
\text { Engineering }\end{array}$ & 2010 & $\$ 126,000$ & $2000 \mathrm{~m}^{2}$ factory & $\begin{array}{l}\text { Construction } \\
\text { cement products }\end{array}$ \\
\hline $\begin{array}{l}\text { LQY Pipe } \\
\text { Manufacturing }\end{array}$ & 2010 & $\$ 9$ million & $5000 \mathrm{~m}^{2}$ factory & Steel pipes \\
\hline $\begin{array}{l}\text { Yulong } \\
\text { Technology } \\
\text { Building } \\
\text { Materials }\end{array}$ & 2010 & $\$ 420,000$ & $\begin{array}{l}10,000 \mathrm{~m}^{2} \\
\text { factory }\end{array}$ & $\begin{array}{l}\text { Gypsum } \\
\text { products }\end{array}$ \\
\hline $\begin{array}{l}\text { Changfa } \\
\text { Agricultural } \\
\text { Equipment }\end{array}$ & 2011 & Unknown & Unknown & $\begin{array}{l}\text { Agricultural } \\
\text { machinery }\end{array}$ \\
\hline Huajian Group & 2011 & $\begin{array}{l}\text { 'Several } \\
\text { millions' } 24\end{array}$ & $\begin{array}{l}\text { Huajian } \\
\text { International } \\
\text { Shoe City }\end{array}$ & $\begin{array}{l}\text { Shoe } \\
\text { manufacturing }\end{array}$ \\
\hline Unilever Plc & 2011 & Unknown & $\begin{array}{ll}5,000 & \mathrm{~m}^{2} \\
\text { workshop } & \end{array}$ & Consumer goods \\
\hline
\end{tabular}




\begin{tabular}{|c|c|c|c|c|}
\hline Eastern Steel & 2013 & $\$ 54$ million & $\begin{array}{l}100,000 \mathrm{~m}^{2} \\
\text { factory }\end{array}$ & $\begin{array}{l}\text { Steel bars and } \\
\text { wire }\end{array}$ \\
\hline $\begin{array}{l}\text { Yangfan Motors } \\
\text { Plc }\end{array}$ & 2013 & $\begin{array}{l}\text { \$2.8 million } \\
\$ 4.5 \quad \text { million } \\
(2014)\end{array}$ & $\begin{array}{l}33,000 \quad \mathrm{~m}^{2} \\
\text { factory } \\
10,780 \mathrm{~m}^{2}\end{array}$ & Motor vehicles \\
\hline $\begin{array}{l}\text { Ethiopia Great } \\
\text { Wall Packing }\end{array}$ & 2014 & $\$ 2.42$ million & $8,000 \mathrm{~m}^{2}$ factory & Packaging \\
\hline $\begin{array}{l}\text { Be Connected } \\
\text { Industries }\end{array}$ & 2015 & $\$ 2.5$ million & $7,000 \mathrm{~m}^{2}$ factory & $\begin{array}{l}\text { Garment } \\
\text { printing }\end{array}$ \\
\hline
\end{tabular}

This rather eclectic array of investors is problematic, as will be discussed below.

Of the companies currently setting up operations in the zone, almost all are Chinese, with the exceptions of Unilever and Be Connected, who are renting facilities (in 2014 Unilever announced it was going to start construction of a new factory). According to the zone operators and also officials at the Chinese embassy in Ethiopia, until Be Connected made their commitment, only one non-Chinese company (from India) had ever expressed any interest in physical investment in the zone. ${ }^{25}$ Ethiopian officials involved in the regulation of the zone claim that numerous companies, all Chinese, have signed letters of intent to invest, but how many will actually follow through on this commitment remains unclear. ${ }^{26}$

The key motive for Chinese investment in the zone is labour exploitation, relatively cheap land and input materials. Against the background of increasing labour costs in China and oversupply in the domestic manufacturing sector, some Chinese producers find Ethiopia attractive. For example, footwear manufacturer Huajian Group, uses the zone to make shoes for the American and European markets:

${ }^{24}$ Helen Hai, Vice President of Huajian Group, quoted in 'Huajian plans to generate USD 4 bln within a decade', Bloomberg News, April 2, 2012.

${ }^{25}$ Ibid and interview with Yang Xuhong, Economic and Commercial Counsellor's Office of the Chinese embassy, Addis Ababa, January 2011. Confirmed in 2014.

${ }^{26}$ Interview with Hagos Sequar, Project Promotion Department Manager of the Eastern Industrial Zone, Addis Ababa, January 2011. 
For Huajian, the major attraction of Ethiopia is its cheap workforce. The average monthly payroll for a worker in Ethiopia is about 300 yuan $(\$ 50)$, compared with 3,000 yuan at its headquarters in Dongguan, Guangdong province. In addition, because animal husbandry output accounts for 20 percent of Ethiopia's gross domestic product, Huajian is using 30 percent of the local leather yield every year, which saves 30 percent in the cost of raw materials...."In general, we can save 18 percent to 28 percent in costs in Ethiopia compared with China" [the general manager at Huajian International Shoe City] said. ${ }^{27}$

An official at the Ethiopian Ministry of Industry openly remarked that: "According to our evaluation, the Chinese choose Ethiopia because of the stable political situation and the land is almost free...Labour is very cheap here too. With 20 birr you can have one day labourer, with 2000-3000 you can have a professional for a month' ${ }^{28}$

Incentives to invest in the zone are no different from those offered to any foreign company looking to invest in Ethiopia, including tax holidays and waivers on import tariffs for raw materials. This includes seven years of income tax holiday for Qiyuan, seven years income tax holiday for enterprises in the zone who produce products mainly for the export market and four years income tax holiday for enterprises that produce for the local market. ${ }^{29}$

The Qiyuan Group has pressed the Ethiopian government to try and arrive at further incentives and concessions. Indeed, one of the authors was at the Ethiopian embassy in Beijing whilst a delegation from Qiyuan was meeting with the ambassador to discuss issues and to 'exchange information' relating to zone policies and the current incentives on offer. ${ }^{30}$ According to the Qiyuan management in Dukem and officials at the Ethiopian Ministry of Trade, a key issue is the ten year 30\% value-added tax (VAT) which Qiyuan is obliged to pay. The Ethiopian government's position is that a decrease does not comply with the principles of competiveness. Qiyuan have also proposed better incentives and preferential policies to compensate for having to

27 'Low Ethiopian Labour Cost Attracts Chinese Investors', China Daily, December 31, 2013.

${ }^{28}$ Interview with Hagos Sequar, Project Promotion Department Manager of the Eastern Industrial Zone, Addis Ababa, January 2011.

${ }^{29}$ See Bulti Terfessa 'Ethiopia's Trade and Investment Policy' in Taye Assefa (ed.) Digest of Ethiopia's National Policies, Strategies and Programs Addis Ababa: Forum for Social Studies, 2010.

${ }^{30}$ Interview with Assefa Alemu, Minister Counsellor at the Ethiopian embassy, Beijing, April 2011. 
build all the infrastructure inside the zone themselves and point to the past situation in Chinese SEZs where, Qiyuan claim, the Chinese government and provincial authorities took care of such infrastructure development. ${ }^{31}$

However, structural weaknesses in Ethiopia's infrastructure (now being addressed by the state's huge investments) limit the value of such largesse. Electricity and water shortages are endemic to Ethiopia. ${ }^{32}$ This has at times impeded the smooth development of the zone and has even led to a wholesale cessation of construction efforts. ${ }^{33}$ Moreover, misunderstandings exist over whether the pledged 30\% from Addis to support the cost of internal infrastructure being built will actually be paid. According to reports, officials in Addis agreed to pay when zone construction is complete. However, some members of the management at the Qiyuan Group expressed concern that this would not be honoured and wanted the costs recovered sooner. ${ }^{34}$ In response, one official at the Ministry of Industry asserted that delivery of the $30 \%$ is guaranteed and that the Chinese developers should not worry, but instead focus on finishing the construction of the zone and begin operations. ${ }^{35}$

In an interview with $\mathrm{Wu}$ Shuaiju of the management of the zone, problems were enunciated. Wu complained that investors cannot obtain title deeds issued by the Government and thus think that their property rights are unprotected. This issue about land title deeds has had a knock-on effect on investment license applications, duty-free applications, construction permit applications and capital loan applications. Qiyuan currently charges enterprises 1.00 ETB ( 5 cents) per $\mathrm{m}^{2}$, the same that Qiyuan paid to Oromia State. Additionally, a one-off land development fee is charged at about 135 ETB (\$6.7) per $\mathrm{m}^{2}$. The main bone of contention for Qiyuan was that its investment on the zone was considerable and that the current estimate is that it will take more than twenty one years to get the investment returned. With an initial development cost of $\$ 180$ million and an

\footnotetext{
${ }^{31}$ Interview with Hagos Sequar, Project Promotion Department Manager of the Eastern Industrial Zone, Addis Ababa, January 2011.

${ }^{32}$ See Daniel Mains 'Blackouts and Progress: Privatization, Infrastructure, and a Developmentalist State in Jimma, Ethiopia', Cultural Anthropology, vol. 27, issue 1, 2012, pp. 3-27.

${ }^{33}$ Interview with Chinese manager, Qiyuan Group, Eastern Industrial Zone, February 2011. This is a problem not unique to the Oriental Zone. During field research at the Lekki Free Trade Zone in Nigeria, Chinese managers at Lekki Free Trade Zone Company, the zone operators, highlighted power shortages as a key problem which they built a power sub-station to address.

${ }^{34}$ Ibid and interview with Chinese manager, Qiyuan Group, Addis Ababa, January 2011.

${ }^{35}$ Interview with Ministry of Industry official, Addis Ababa, February 2011.
} 
income budget of \$7.5 million, it appears that only after twenty four years will Qiyuan start making money on the project. ${ }^{36}$ Similarly, in an interview with Yin Tianjun, director of Lifan's car assembly factory in the zone, Yin complained of high import tariffs, consumption taxes and expensive transportation costs. Although labour is much cheaper than in Ethiopia, Yin claimed that this was offset by high duties, meaning that the price of a Lifan car is almost triple the price found in China. ${ }^{37}$

Yet a recent report by World Bank highlighted the fact that financial incentives are not in fact correlated with SEZ success. Rather, a strong host business and investment climate is decisive. In other words, what is "special" about SEZs is not so much the financial incentives offered to investors, but rather the business environment which SEZs provide. Incentives are but just one aspect. The resolve of the relevant Ethiopian bodies regarding the incentives issue, therefore, should be viewed in a positive light, evidence that the Ethiopian government is less concerned with minor issues and perhaps instead focussed on the factors correlated with zone success. In contrast, the Chinese side seem fixated on what incentives they can prise out of Addis.

The Ethiopian government is publicly committed to maintaining macroeconomic stability and developing an improved financial sector. ${ }^{38}$ Regulations have been simplified, customs times reduced, and business licenses are substantially cheaper and easier to obtain than before. ${ }^{39}$ Moreover, adhering to the belief that a strong private sector is vital for Ethiopia's development, reforms have been initiated designed to encourage the development of a stronger and more competitive private sector. ${ }^{40}$ The investment code has been amended several times as a means to satisfy the ostensible demands of both domestic and foreign investors. ${ }^{41}$ The government of Ethiopia is not being passive and letting foreign investors do what they want or get what they want

${ }^{36}$ Interview with Wu Shuaiju, Eastern Industrial Zone, cited in Ethiopia Herald, January 14, 2015. ${ }^{37}$ Interview with Yin Tianjun, director of Lifan Motors Plc, cited in China Daily, December 31, 2013.

${ }^{38}$ See Dan Ciuriak and Claudius Preville 'Ethiopia's Trade and Investment: Policy Priorities for the New Government', unpublished paper, September 2010.

39 Asayehgn Desta Ethiopia: From Economic Dependency and Stagnation to Democratic Developmental State Trenton, NJ: Red Sea Press, 2014.

${ }^{40}$ Admit Zerihun 'Industrialisation Policy and Industrial Development Strategy of Ethiopia' in Taye Asefa (ed.) Digest of Ethiopia's National Policies, Strategies and Programs Addis Ababa: Forum for Social Studies, 2008, p. 10.

${ }^{41}$ See Solomon Mamo Woldemeskel Determinants of Foreign Direct Investment in Ethiopia, Master's thesis submitted to Maastricht School of Governance, Maastricht University, 2008. 
and is proactively defending perceived Ethiopian interests. As one officer at the Ministry of Industry tasked with overseeing zone operations explained: 'We will not budge on the VAT tax we are offering the Chinese developer. They [the Qiyuan Group] want us to reduce it, but if they think we will do so, they are mistaken'. ${ }^{42}$ This is perhaps evidence of the Ethiopian government exercising its regulatory role and, equally, playing a role as a partner, not a bystander, although it should be noted that many African governments are reluctant to concede on VAT.. ${ }^{43}$

The planning, resolution and execution of the zone initiatives groups together a number of agents and stakeholders, such as central governments in Ethiopia and China, local governments in Ethiopia, national investment promotion agencies, private businesses, interest groups and local communities. Unlike in China, where government agencies generally took the lead in formulating and implementing SEZ projects, in Ethiopia, as in the some other MOFCOM-approved African zones, private enterprises were at the helm. It was only with the formation of the IPDC that we can say that Addis began taking charge.

The Chinese government (mainly through the embassy in Addis) provide guidance and support, but they do not get involved in the business side of the project - this is left to the investor. The Qiyuan Group's relationship to the Chinese embassy in Addis mainly consists of the latter helping establish and co-ordinate relations with Chinese companies and parties interested in investing in Ethiopia. ${ }^{44}$ But beyond this, the involvement of the embassy is minimal. This fits with previous studies which have found that:

[T]he Chinese government has taken a 'hands off' attitude towards African policies on these zones. We could find no evidence or even rumours of conditionalities or quid-proquos imposed on host governments by the Chinese government in return for the development of the zones. While the Chinese government played a role at the diplomatic level and in visits by Chinese leaders to some (but not all) of the countries hosting zones, our interviews make it clear that Chinese companies, with the support of their local

\footnotetext{
42 Interview with Hagos Sequar, Project Promotion Department Manager of the Eastern Industrial Zone, Addis Ababa, January 2011.

${ }^{43}$ Ethiopia has long had a relatively strong and competent state. See Christopher Clapham Haile Selassie's Government New York: Pragaer, 1969; Tsegaye Tegenu The Evolution of Ethiopian Absolutism: The Genesis and the Making of the Fiscal Military State (1696-1913) Los Angeles: Tsehai Publishers, 2007.

${ }^{44}$ Interview with Yang Xuhong, Economic and Commercial Counsellor's Office of the Chinese embassy, Addis Ababa, January 2011.
} 
embassy, took the lead in negotiations with host governments over particular incentives and responsibilities, particularly for infrastructure construction. ${ }^{45}$

Within Ethiopia, consensus on the EIZ initiative was slow to arrive, particularly the merits or otherwise of allowing a private corporation to drive the process. Initially it seemed that the Ethiopian government believed that having a private enterprise in charge of the planning, implementation and operation of the zone had advantages that state-led initiatives are unable to realise. According to one senior official at the Ethio-Chinese Bilateral Commission in Addis Ababa, 'the [Ethiopian] government hopes that the zone developers will be less vulnerable than our companies, and that they will be in a better position to access global markets and capital. They will also have the know-how which we simply don't have' ${ }^{46}$ Capitalizing on the strengths of private enterprises and their experience and knowledge of the global markets alongside their operating procedures was one way that the Ethiopian government believes Ethiopian actors involved in the zone may benefit and develop.

However, the formation of the IPDC in 2014 signalled a step up in direction. ${ }^{47}$ The IPDC is fully mandated to develop industrial parks in Ethiopia. As a public enterprise, owned and supervised by the government, infrastructure connecting industrial parks with Ethiopia's core infrastructure is also part of the IPDC mandate. This joined-up strategy is indeed noteworthy. The IPDC aims to provide a one-stop-shop service for those investing in designated industrial parks in collaboration with the Ethiopian Investment Commission (EIC), the Ethiopian Revenues and Customs Authority (ERCA) and others. The Ethiopian government's strategy still acknowledges the role of the private sector as an engine in the industrialization process. Within this framework, efforts to enhance responsible capitalism is central. By this, the government makes a clear distinction between "rent-seeking" and "developmental" capitalists, with the latter obviously being favoured. Yet Addis also maintains that the state must play a strong role in development, 'not merely as a facilitator but also as a leader (i.e., providing direct support, co-ordinating and guiding

\footnotetext{
${ }^{45}$ Deborah Brautigam and Tang Xiayang, 2011, p. 35.

${ }^{46}$ Ibid.

${ }^{47}$ The government had approved the establishment of the Ethiopian Industrial Zones Development Corporation (IZDC) in 2012, but the corporation was not particularly active and it was reestablished as the Ethiopian Industrial Park Development Corporation (IPDC) in 2014 with a new directive.
} 
the private sector). Inspired by the East Asian experience the government has recently introduced the language of "developmental state" as its policy principle regarding the state-business relationship'. 48

\section{Catalytic potential?}

A key component of the SEZ paradigm is to move away from the protected and isolated importsubstitution approach of the past towards one ostensibly guided by international competitiveness, regional co-operation and a more diversified, private-driven ownership pattern. ${ }^{49}$ In this sense, the SEZs purport to be targeted attempts to stimulate economic growth by creating globally competitive spatial entities through new investments, infrastructural development and jobs creation. ${ }^{50}$ Through these initiatives, the host state seeks to "crowd in" private investment in order to unlock inherent economic potential in a specific spatial location with unrealised economic potential. ${ }^{51}$ The basic task is to use existing frameworks and/or construct new ones as a means to formulate a certain geographic space by which the existing economies can be developed and diversified. ${ }^{52}$ In the study of SEZs this has been termed the 'catalytic effect' where there is potential for SEZs to engender dynamism in the economy beyond the spatial restrictions of the zone and stimulate development. ${ }^{53}$ Cheesman defines the catalytic effect as 'interaction with the domestic economy: specifically they deal with industrial spillovers and the establishment of zonedomestic linkages'. 54

For Ethiopian proponents of the zone the aim is clear: to support sustainable industrial development, whilst the Chinese equally claim that 'the purpose of our Eastern Industrial Zone is

${ }^{48}$ Mulu Gebreeyesus Industrial Policy and Development in Ethiopia: Evolution and Present Experimentation Africa Growth Initiative at Brookings, Working Paper no. 6, 2014, p. 22

49 Yue-man Yeung, Joanna Lee, and Gordon Kee 'China's Special Economic Zones at 30', Eurasian Geography and Economics, vol. 50, no. 2, 2009, pp. 222-240.

${ }^{50}$ Alexius Pereira State Collaboration and Development Strategies in China London: Routledge, 2003.

51 Thomas Farole and Gokhan Akinci Special Economic Zones: Emerging Challenegs and Future Directions Washington DC: World Bank, 2011.

${ }^{52}$ Ligang Song and Ross Garnaut China: Linking Markets for Growth Canberra: Asia Pacific Press, 2007.

53 Johansson H. and L. Nilsson (1997). 'Export Processing Zones as Catalysts', World Development, 25(12):2115-128.

${ }^{54}$ Andrew Cheesman Special Economic Zones \& Development: Geography and Linkages in the Indian EOU Scheme London: Development Planning Unit Working Paper no. 145, 2012, p. 8. 
to make contributions to the economic development of Ethiopia' ${ }^{55}$ Of course, Chinese enterprises hope to gain competitive advantages in their trading networks (access to new markets and areas of unique competitive advantage).

According to Tadesse Haile, the Ethiopian Minister of Industry, over the next ten to fifteen years Ethiopia aspires to evolve from an economy based on agriculture (currently accounting for over $40 \%$ of national GDP and $85 \%$ of national employment) to an industrialised middle-income economy. Policy makers in Addis believe that improved living standards, reduction in poverty, and greater agency in global affairs will only be achieved once Ethiopia has industrialised. As the Ethiopian Minister of Industry Minister has asserted, 'industrialisation is the benchmark for transforming an economy' helping to foster investment and innovation. ${ }^{56}$

With a low investment capital base in Ethiopia, and a weak local bourgeoisie (which is critiqued by the Ethiopian government as being parasitic and dependent on the state bureaucracy), ${ }^{57}$ Addis is looking to foreign investors to act as a vehicle to help speed up the process of industrialisation. ${ }^{58}$ As one official at the Ethio-Chinese Bilateral Commission explained:

[f]oreign investment is critical to Ethiopia's development and we must do what we can to maximize it to keep our economy on a path of growth. We need to modernise and reach international standards. Linking with countries like China who have better experience and resources in this regard is vital to Ethiopia's modernisation efforts. ${ }^{59}$

The EIZ is held to be capable of acting as a catalyst for innovation and development and inspiring the Ethiopian government to plan six new industrial zones around Addis based on the model. ${ }^{60}$

\section{Untargeted development?}

55 Interview with Wu Shuaiju, Eastern Industrial Zone, cited in Ethiopia Herald, January 14, 2015.

56 Tadesse Haile, Ethiopian Minister of Industry, Fourth China-Development Assistance Committee (DAC) Study Group conference, Addis Ababa, February 2011.

${ }^{57}$ Meles Zenawi Fundamental Questions of Democracy in Ethiopia Addis Ababa: EPRDF, 2001, p. 32.

58 Tsegaye Tegenu 'The Idea of Industrialization in Ethiopia: Fundamental Issues for Debate', unpublished paper, May 25, 2011, p. 1.

${ }^{59}$ Interview with Tilahun Tadesse, Acting Director of the Ethio-Chinese Bilateral Commission, Addis Ababa, January 2011.

${ }^{60}$ Interview with Assefa Alemu, Minister Counsellor at the Ethiopian embassy, Beijing, April 2011. 
The EIZ is, at present, noticeable for it's rather scattergun approach with regard to the types of industries located in the zone. The diversity of industries is problematic given that influential development theory argues that a more directed and steered industrial policy is needed in late developers, even if this is at the expense of a broad-based strategy. This critique of the EIZ, based on the work of Alexander Gershenkron and Albert Hirschman, raises important questions about the efficacy of the EIZ as it is currently developing. Indeed, synchronic solutions to the problem of industrialization, which the EIZ assumes, is less likely to be effective than sequential solutions.

Alexander Gerschenkron initially applied the concept of "substitute factors" to the study of so-called "latecomer" economies. ${ }^{61}$ Rejecting the idea of a one-size-fits-all model of industrialisation, Gershenkron recognised the partiality and specificities of development. ${ }^{62}$ Albert Hirschman's conceptualisation of sequencing followed this line of thought. This was a rejection of the dominant idea that required "balanced growth", whereby the industrial sector is seen as an inseparable and amalgamated enterprise, 'like one huge firm or trust'. ${ }^{63}$ Instead, Hirschman argued that development policies should foster a distortion in profits and investments in accordance with a predesigned industrial strategy, as it is these imbalances that facilitate economic growth. ${ }^{64}$ The targeting of sectoral development, rather than attempting a broad-based approach was, according to Hirschman, particularly important in resource-poor economies (such as Ethiopia). For example, an investment project aimed at an output industry, which at first has to import its equipment and inputs, may be planned so that it promotes the production of this machinery and inputs domestically, by other companies. This then may help stimulate domestic capital formation and backward linkage through the inputs. At the same time, it is also imaginable to set up investment projects so that developments in the focussed input industries promote extant output industries, or even lead to the materialisation of new output industries i.e. forward linkages. ${ }^{65}$ The targeted

\footnotetext{
${ }^{61}$ Alexander Gershenkron Economic Backwardness in Historical Perspective Cambridge, Mass.: Belknap Press of Harvard University Press, 1962.

${ }^{62}$ See his critique of Walt Rostow's "Modernisation Theory" in 'The Typology of Industrial Development as a Tool of Analysis' in Alexander Gershenkron Continuity in History and Other Essays Cambridge, Mass.: Belknap Press of Harvard University Press, 1962, pp. 78-79.

${ }^{63}$ Paul Rosenstein-Rodan 'Problems of Industrialisation of Eastern and South-Eastern Europe', Economic Journal, vol. 53, no. 209, 1943, p. 204.

${ }^{64}$ Albert Hirschman The Strategy of Economic Development New Haven, CT: Yale University Press, 1958.

65 Albert Hirschman 'Linkages in Economic Development' in Albert Hirschman Rival Views of Market Society and Other Essays Cambridge, MA: Harvard University Press.
} 
sectors then, ideally, develop into the primary sectors of the economy. Development follows as growth in the key sectors spreads to others. Hirschman also postulated two separate processes of stimulating an unbalanced growth strategy: investments in basic services that support primary, secondary and tertiary production sectors (Social Overhead Capital or SOC) and Directly Productive Activities (DPA). ${ }^{66}$

Significant investment in SOC will animate investment in DPA by delivering cheap inputs to agriculture and industry. For example, low-cost electricity and an efficient power supply network may support the development of industries as well as stimulating movement in other sectors. As Hirschman notes, 'Investment in SOC is advocated not because of its direct effect on final output, but because it permits and in fact invites DPA to come in some SOC investment as a prerequisite of DPA investment'. ${ }^{67}$ Imbalances in the economy may also be fashioned by investment in DPA such as investment in manufacturing industries and construction. Growth in investment in DPA without a matching increase in SOC will likely lead to a rise in production costs due to insufficient overhead facilities. If this happens, stresses are likely to develop and the state could intervene and embark on investment in SOC to generate the needed infrastructure so as to stimulate development of the economy.

The progression of development from SOC to DPA is referred to as development via excess capacity. The second sequence i.e. from DPA to SOC is termed development via shortages. Development through an excess of capacity of SOC is less problematic than development via deficiencies of SOC: 'development via shortages is an instance of disorderly compulsive sequence while that with excess SOC capacity is essentially permissive'. ${ }^{68}$

The concept of unbalanced growth has re-emerged in developmental economics, albeit not always overtly. Recent literature ranges from a U-shaped pattern of sectoral diversification during the development process to broader industrial policy discussions. ${ }^{69}$ Indeed, industrial policy is now very much back on the agenda of African development. ${ }^{70}$ In an important study, Cohen

\footnotetext{
${ }^{66}$ Hirshcman, 1958, pp. 83-97.

${ }^{67}$ Ibid., p. 84.

${ }^{68}$ Ibid., p. 87.

${ }^{69}$ Jean Imbs, Romain Wacziarg 'Stages of Diversification',.American Economic Review, vol. 93, no. 1, 2003, pp. 63-86.

${ }^{70}$ Lindsay Whitfield, Ole Therkildsen, Lars Buur and Anne Mette Kjær The Politics of African Industrial Policy: A Comparative Perspective Cambridge: Cambridge University Press, 2015.
} 
differentiates vertical (sector-specific) and horizontal (framework) industrial policies and it is quite clear that Hirschman's unbalanced growth postulation matches the vertical industrial policy classification. ${ }^{71}$ There have also been attempts to make a distinction between industrial policy "in the small" (introducing mechanisms to recognise and eliminate "roadblocks" hindering existing economic undertakings) and industrial policies "in the large" (essentially strategic prioritisation on favoured industries; the linkage aspect of the unbalanced growth premise offers a standard for making policy decisions in this regard. ${ }^{72}$

At first glance, the SEZ model appears to follow the logic outlined by Gershenkron and Hirschman, given that a spatially concentrated location of economic activity is prioritised (acting as substitute factors) over other parts of the economy (unbalanced growth). This has been the case with other SEZs. ${ }^{73}$ Indeed, the EIZ may be seen as nominally functioning as SOC. Yet the EIZ's stated raison d'etre is its embeddedness in Ethiopia's economy and it is not supposed to be simply some enclave assembling products for the external market. Far from it, the EIZ claims to act as a catalyst for Ethiopia's wider industrialisation, which necessitates a strong connection between the economy of the EIZ and the local economy. SOC investment in a spatially constrained area with minimal backward and forward linkages will not lead to DPA outside of the zone.

Fundamental to this is that growth needs to be transmitted from one sector to another, with robust backward and forward linkages across sectors. Hirschman stressed that backward linkages were of greater importance, as sectors with solid backward linkages instinctively generate input requirements. However, when one considers the enterprises currently active in the EIZ, the broader developmental possibilities appear minimal. Very few have even reasonably durable backward linkages, with most being operations with low levels of employment opportunities. It is not good enough to argue that the EIZ offers up the possibilities of technology transfers, as the literature observes that capacity for transfer spillovers is most pronounced where the differences between incoming investment and the local economy is least and that such transfers 'should be for

71 Elie Cohen 'Industrial Policies in France: The Old and the New. Journal of Industry', Competition and Trade, vol. 7, nos. 3-4, 2007, pp. 213-227.

72 See Ricardo Hausmann, Dani Rodrik and Chales Sabel Reconfiguring Industrial Policy: $a$ Framework with an Application to South Africa Center for International Development at Harvard University Working Paper, no. 168, May 2008

${ }^{73}$ See John M. Litwack and Yingyi Qian 'Balanced or Unbalanced Development: Special Economic Zones as Catalysts for Transition', Journal of Comparative Economics, vol. 26, issue 1, 1998. 
appropriate sectors and at appropriate levels'. ${ }^{74}$ A recent study on the effect of Chinese inward FDI into Ethiopia confirms that the investment only has a positive spillover effects for Ethiopian industry when the technology gap between the Chinese and domestic firms is small, and that domestic firms with lower absorptive capacity suffer negative spillover effects from the FDI flows. ${ }^{75}$ Hi-tech investment in an economy like Ethiopia's is least likely to have beneficial results, particularly when the backward linkages are minimal. The catalytic effect potential of the EIZ is then probably insignificant

A problem that is now only be addressed lies in the fact that until recently (2014) the government in Addis Ababa took a rather hands-off approach to the EIZ idea. What SOC that was occurring wa to the benefit of the Chinese investors, rather than the wider economy. In China, the SEZ model was implemented within a very specific political and economic context, where the state was generally able to capably "direct" development through SOC and DPA. This was absent in Ethiopia until the IPDC formation, which of course is a positive development. This is particularly so given that a study by the World Bank noted that, '[c]ountry context is likely to be critical in the outcomes of any SEZ program, so it may be implementation rather than policy and design that is the most critical factor in determining the success of an SEZ program'. ${ }^{76}$ Understood in this way, it seems that for a SEZ to develop successfully it is a case of not what, but how. As the Bank's report makes clear, this requires the right framework, taking into consideration the host country (its comparative market advantage and political economy, including political will) and utilising the know-how and experience of the investors and developers. It seems that Addis realised this fairly early on in the EIZ experiment as further industrial parks were envisioned. Thus a special research unit from the Ministry of Industry in Ethiopia was created and tasked with travelling to and investigating different SEZs around the world, identifying what was and what was not appropriate to the Ethiopian situation. As the then head of the unit explained to one of the authors:

\footnotetext{
${ }^{74}$ David Bennett and Kirit Vaidya 'Technology Transfer and Sustainable Industrial Development for Developing Countries', in Mike Gregor and Shi Yongjiang (eds.) Restructuring Global Manufacturing: Towards Global Collaborative Supply Networks Cambridge: Cambridge University Press, 2002, p. 22.

${ }^{75}$ Mebratu Seyoum, Renshui Wu and Li Yang 'T echnology Spillovers from Chinese Outward Direct Investment: The Case of Ethiopia', China Economic Review, vol. 33, April 2015.

76 Thomas Farole, 2011, p. 127.
} 
The problem that I see on our side is that we are not ready to support and guide the investors so there could be some hindrances when they start investing. Now the government is paying attention and we are starting to study the legal framework on how to supervise or how to support based on international practice. But we are conscious not to make the mistake that other developing countries have made in thinking that we can just copy the exact SEZ model of other countries. ${ }^{77}$ The IPDC's role in such a milieu is likely to be vital.

At a conference held in Ethiopia in 2011 focusing on creating the "right" enabling environment for enterprise development, a recurring theme was apparent: China's development model was right for China and whilst certain lessons can be taken from China's development experience, its policies and framework should not be simply replicated in developing countries, but rather serve as a point of reference. ${ }^{78}$ This included China's success with SEZs. Experimental in nature, SEZ strategies were said to actively absorb foreign ideas, but adapt them appropriately to the local environment. ${ }^{79}$ The concrete results of such thinking was the formation of the IPDC, a state institution explicitly mandated to offer up a coordinating service for investors considering investing in the designated industrial parks (which includes EIZ). Ethiopia has also drafted a new Special Economic Zones law 'based on international best practices' to guide the governance, development and operation of SEZs in the country. ${ }^{80}$

Yet despite these potentially positive moves, as well as designing and implementing SEZ programmes appropriate to the host country's economic (and political) context, SEZs must be part of a broader and more dynamic national economic development strategy that links SOC with DPA. But this need strategizing. Simply crowding in diverse investors from China into a concentrated geographic space, with no control over the types and levels of technologies that the investors bring

\footnotetext{
${ }^{77}$ Interview with Hagos Sequar, Project Promotion Department Manager of the Eastern Industrial Zone, Addis Ababa, January 2011.

78 The conference was held in Addis Ababa between 16-17 February 2011 on the theme: "Enterprise Development and Economic Transformation: Creating the Enabling Environment", organised by the China-DAC Study Group.

79 Sonoko Nishitateno 'China's Special Economic Zones: Experimental Units for Economic Reform', International and Comparative Law Quarterly, vol. 32, issue 1, 1983, pp 175 - 185.

80 'Industry Zone Development', Ethiopian Investment Commission, http://www.investethiopia.gov.et/investment-opportunities/strategic-sectors/industry-zonedevelopment, accessed December 7, 2015.
} 
or the depth of linkages that can be developed to the local economy, is unlikely to be optimal. The news in October 2015 that a delegation of ten major Chinese pharmaceutical and medical supplies companies had visited the EIZ with a view to investing is indicative of this unfocused approach. ${ }^{81}$ Whilst the visitors claimed to be interested in partnering with local companies to manufacture drugs, the initiative is yet another diversification of industries being collated at the EIZ and again undermines its potential as a catalysts for development through a targeted strategy of uneven growth. Whilst all potential projects are said to be in the form of joint ventures with Ethiopian companies, tying in with the demands of the government's Growth and Transformation Plan (GTP II), the ability to structurally transform Ethiopia's economy remains to be seen. ${ }^{82}$ What is interesting in this regard is that the planned industrial parks operated or owned by the state (under the rubric of the IPDC) are far more concentrated and targeted. Further research on these zones (most of which are only in the planning or design phase) will clarify whether or not Hirschman's theory of targeting sectoral development, rather than endeavouring a broad-based method (as exemplified in the EIZ) is applicable to Ethiopia.

\section{What Chance of Success?}

The potential of the Chinese EIZ to have any meaningful effect on development in Ethiopia is uncertain. Firstly, the zone itself has been considerably downsized from the originally planned area of eight square kilometres to a mere two square kilometres. Though this was due to the developers' financial problems and the inability to muster enough investors, the fact that the central government in Beijing, which has marketed SEZs in Africa as a flagship projects symbolising Chinese commitment to "win-win" outcomes and "mutual benefit" did not step in and offer assistance is perhaps a sign of its ambivalence towards the initiative beyond the rhetoric. Here it should be pointed out that the China-Africa Development Fund (CADF) (China's prime investment vehicle in Africa) is not involved. The CADF is involved in three of the seven African zones (Lekki in Nigeria, Suez in Egypt, and Mauritius) and has considerable expertise, thus its decision not to invest in the Ethiopian zone suggests at the very least that the Fund holds some degree of scepticism towards its potential.

81 'Ethiopia to See Potential Chinese Pharma Investment', Addis Fortune, October 26, 2015.

${ }^{82}$ See Federal Democratic Republic of Ethiopia Growth and Transformation Plan, 2015/16 to 2019/20 Addis Ababa: Ministry of Finance and Development, 2015. 
Interestingly, in contrast to the Ethiopian case, in the Lekki Free Trade Zone (LFTZ) in Nigeria, at the request of the government of the host Lagos State, Beijing did intervene to restructure the consortium of Chinese companies involved in the operation of the zone and increased the China Civil Engineering Construction Corporation's (CCECC) stake from 25\% to $75 \%$. This can be seen as evidence of the political and commercial importance that the Chinese government attaches to the successful development of the LFTZ in Nigeria, and the potential it sees in the zone. Also of note, in Nigeria Beijing sent a delegation from MOFCOM to audit the accounts of the Lekki Free Trade Zone Company, the 40\% Nigerian/60\% Chinese joint venture created to operate the zone. ${ }^{83}$ Beijing has also stepped in to solve problems in the Chinese SEZs in Mauritius and in Zambia, and former President Hu Jintao attended the opening ceremony of the Zambia-China Economic and Trade Cooperation Zone. In contrast, there has been no intervention by the Chinese government in Ethiopia, even after the Qiyuan Group, with no previous experience in developing a SEZ, continued to develop the zone after initial partners pulled out.

Currently, policymakers and government officials alike seem to regard the SEZ as little more than a fancy industrial zone, created to facilitate foreign (i.e. Chinese) investments focused on light industries. As Arkebe Oqubay, a senior adviser to Ethiopia's prime minister, recently noted, too many SEZs in Africa are underwritten by outsiders and are 'a kind of fad that is seen as a solution for everything' despite the fcat that it is obvious that such industrial parks cannot be 'a replacement for the basics' ${ }^{84}$ What is remarkable about this situation is that it once again replicates the weaknesses that characterised previous attempts in Africa to set up industry clusters: poor infrastructure, fragile ties to sources of innovation and technology, and a broad absence of state support. ${ }^{85}$ Inappropriate technology levels and the absence of beneficial linkages to the domestic economy might also be added to this set of problems. Whilst Addis Ababa talks loudly about industrialisation and developing Ethiopia, it is in fact the Chinese investors that have put up the bulk of the capital and shouldering the majority of the risks involved. Time will tell whether the IPDC's industrial parks will be qualitatively better. However, at least it may answer some of Eshetu Chole's warnings:

${ }^{83}$ Interview with Fang Li, Marketing Manager Lekki Free Trade Zone Company, Lagos, Nigeria, December 2010.

${ }^{84}$ Quoted in 'Seeds of Industry', China Daily, July 17, 2015.

${ }^{85}$ Deborah Brautigam and Tang Xiayang, 2011, p. 28. 
[W]here industrialisation has been successfully implemented, it was under the leadership of an indigenous capitalist class or a strong state. In the absence of such a class in the Third World, ownership and leadership of industry has fallen in the hands of foreign entrepreneurs or those of the state, or some combination of these. Where foreign enterprise has the upper hand, whatever industrialisation takes place is likely to be dependent, that is without any organic domestic base, and therefore fragile. ${ }^{86}$

\section{Conclusion}

The most important implication of this study is that policymakers must understand and engage with the interaction among and between industrial structures, linkage potentials, and the political economy of a given situation. Host governments where SEZs have been successful have taken advantage of the dynamic potential of the zones as an instrument of sustainable structural economic transformation. This currently does not yet exist in Ethiopia. Indeed:

Weak information flows, risk aversion, and a poor environment for investment protection and contract enforcement in Ethiopia combine to foster entrepreneurial conservatism. The result is personalised business relations, exceptionally low productivity, and the pursuit of opportunistic rents in often dysfunctional markets. These factors have allowed efficient and inefficient businesses to continue to coexist, leaving domestic business vulnerable to international competition as sectors are opened. ${ }^{87}$

The fact that the Eastern Zone is operated by a wholly owned Chinese venture and that no Ethiopian businesses are investing in the zone means instead that significant levels of technology and knowledge transfer are highly unlikely to take place. ${ }^{88}$ Nor are backward linkages, as Hirschman identifies so clearly, likely to be of any significance. While the EIZ developers claim that they are very willing to work with local companies in Ethiopia and that they actively encourage Ethiopians to invest in the zone, in practical terms, capital investment required to obtain a stake in the zone prevents this from happening. This then has led some Ethiopians to believe that rather

${ }^{86}$ Eshetu Chole Underdevelopment in Ethiopia Addis Ababa: Organisation for Social Science Research in Eastern and Southern Africa, 2004, p.154.

${ }^{87}$ Sarah Vaughan and and Mesfin Gebremichael, 2010, p. 11.

${ }^{88}$ Interview with Dessalegn Rahmato, Researcher and Private Consultant, Addis Ababa, September 3, 2013. 
than being an initiative aimed at assisting Ethiopia's industrialisation, the Eastern Industrial Zone is in fact designed to facilitate the expansion and penetration of Chinese private enterprises into Africa, and that the former (industrialisation) may be just an incidental offshoot of the latter, at best. ${ }^{89}$ Such an analysis would confirm Andrew Shrank's general prognosis on such economic zones. ${ }^{90}$

Yet the decision announced by Addis that it was going to invest $\$ 1.3$ billion for industrial parks, with \$700-750 million coming from sovereign bonds issued by the state reflects an expression of faith in the workability of these spatially concentrated industrial nodes. ${ }^{91}$ Whilst the IPDC has (understandably for political reasons) sought to spread the geographic range of these planned parks a problem immediately arises: all previous experiences of economic zones demonstrates the need to prioritise development based on site selection criteria so as to make sure that the different zones do not end up competing with each other. That there is sufficient demand to fill all proposed sites is another basic principle and it is unclear where the Ethiopian government believes it is going to get the necessary investors for their expansive programme given Ethiopia's infant private sector, underdeveloped transport facilities and unpredictable infrastructure and utilities. If the hope is that foreign investors will fill the gap, the question of dependent development comes to the fore. This is something that the state in Ethiopia will have to carefully manage.

Remaining with the EIZ, if local companies cannot afford to invest in the zone, and it is not financially feasible for the bigger companies to shift operations from their current location into the zone (which in itself is somewhat geographically remote), then the Eastern Zone will be of possible limited benefit to Ethiopia. Technology and knowledge transfer or spill-over, a fundamental aspect of any claimed SEZ model, will not occur if Ethiopians are unable to access the opportunities in the zone. Evidence suggests that, at best, Ethiopian involvement in the zone will be limited to providing cheap labour and the supply of some basic low-grade input materials (primarily in the shoe factory). Thus the assertion that Ethiopia 'could become the China of Africa'

${ }^{89}$ Interview with Ethiopian businessmen during Fourth China-DAC Study Group conference, Addis Ababa, February 2011.

${ }^{90}$ See Andrew Shrank 'Export Processing Zones: Free Market Islands or Bridges to Structural Transformation?', Development Policy Review, vol. 19, no. 2, 2001, pp. 230-233.

91 'Ethiopia Earmarks \$1.3 bn for First Phase Industrial Parks', Addis Fortune, November 24, 2015. 
in terms of industrialisation is unlikely. ${ }^{92}$ What is more likely is that the 'China of Africa' element will consist of very low wage levels, enabling profit maximisation for the investors. The EIZ then will not perform its task as a substitute factor in spurring development or stimulating significant DPA. This contradicts previous studies such as by Brautigam and Tang, but is in line with the conclusions drawn by studies of Ethiopia's industrial policies by Ethiopian academics and others. ${ }^{93}$ For instance, the World Bank's latest report on the state of Ethiopia's economy is less bullish about the industrial zones (IPs) performance in the country:

The inexistence of IP-related policies and management experience led to multiple challenges in planning and implementing of the EIZ and Bole Lemi 1 industrial parks. A range of issues have held back the performance of the program, including...lack of an effective and functioning policy, regulatory and institutional framework; weak strategic planning and demand-driven approach; poor on-and-off site infrastructure planning; lack of specific on-and-off-site costing, performance agreements, and economic and financial analysis; absence of institutional capacity to oversee IP development; inefficient procedures and controls, including customs administration; lack of systematic investment promotion to attract committed anchor investors; and deficiencies in designing and implementing a linkages program, a communications and outreach strategy, and establishing and tracking performance indicators. These factors, combined with a poor business environment and weak eco-system related to skills and technology, have not led to the envisaged outcomes. ${ }^{94}$

From interviews with people living around the zone in Dukem and in Addis Ababa, concerns were common around the questions of how the EIZ would translate into employment opportunities and how might this then facilitate a better quality of life. At the moment, employment generation is the main (if not sole) benefit of the Eastern Zone for the local population. This will likely stay the same for years to come as the zone develops and matures from the preliminary developmental

\footnotetext{
92 'Ethiopia Becomes China's China in Search for Cheap Labor', Bloomberg News, July 22, 2014 $<\quad$ http://www.bloomberg.com/news/articles/2014-07-22/ethiopia-becomes-china-s-china-insearch-for-cheap-labor $>$

${ }^{93}$ See Arkebe Oqubay, 2015.

${ }^{94}$ World Bank $4^{\text {th }}$ Ethiopia Economic Update: Overcoming Constraints in the Manufacturing Sector Washington DC: World Bank, 2015, pp. 45-46.
} 
stage and early operational stages. ${ }^{95}$ Officials in Addis hope that when experience levels in Ethiopia increase, particularly in the management and understanding of the zone operations, then the more dynamic benefits for Ethiopians will accrue as they begin to take charge of the management of zone operations and become responsible for its continued growth and development. ${ }^{96}$ But this ambition remains vague and in any case is unlikely to generate substantial employment opportunities with a high skills transfer content. The bulk of the workforce in the EIZ will remain low-skilled, low-paid.

The government in Addis Ababa is strongly focussed on attracting FDI. ${ }^{97}$ Such policies are, in the absence of lucrative and easily exploitable resources, reliant on an investment climate where investors feel secure. ${ }^{98}$ Given that infrastructure (or lack thereof) is one of Ethiopia's main barriers to attracting significant foreign investment, the SEZ may provide one way to address this issue, albeit necessarily confined to a small locale. However - and this goes to the heart of the viability of the SEZ in Ethiopia - even having world-class infrastructure (SOC) within the gates of a SEZ loses any advantages if the infrastructure outside the zone is poor (as it generally is in Ethiopia) and linkages to the local economy are minimal. This is why the government's huge investment in Ethiopia's infrastructure is so important.

Currently the Eastern Industrial Zone is in the early stages of development and it could be argued that evaluations such as ours are premature. On the positive side, it could be suggested that for the Ethiopian government a number of short term objectives have already been achieved, most notably attracting foreign (even if mainly only Chinese) investment and the institutional development of an improved investment climate. The establishment of the IPDC, which has clearly been influenced by the Chinese SEZ experience as well as ambitions to construct a developmental state in Ethiopia can alos be seen to be positive. It was certainly a coup on the part of Ethiopia to be chosen by Beijing to host one of the Chinese SEZs in Africa.

\footnotetext{
${ }^{95}$ Within the initial feasibility studies, Qiyuan did express an interest in building clinics and schools for local community but so far they have not started to do this. Moreover, they are not obliged to do so.

${ }^{96}$ Interview with Alemayehu Geda, Addis Ababa University, January 2011.

97 Amanuel Mekonnen Workneh 'Factors Affecting FDI Flow in Ethiopia: An Empirical Investigation', European Journal of Business and Management, vol.6, no.31, 2014.

${ }^{98}$ See Melakou Tegegn State and Civil Society: Ethiopia's Development Challenges Los Angeles: Tsehai Publishers, 2013.
} 
As the zone develops analysts will need to study to what extent does this zone in Ethiopia act as a substitute factor for DPA and development and how deep are its linkages to the Ethiopian economy, as well as to what extent does the zone provide easily accessible opportunities for the domestic business community and the local population? This will likely be the focus of future research on the Chinese SEZs in Africa, allowing the identification of whether or not the SEZ framework is appropriate and effective in the African context, and whether or not host countries are best utilising the dynamic catalytic potential of SEZs to generate long-term sustainable development. The ability of the state-owned industrial parks will be similarly evaluated.

Future analyses will necessarily take place within the context whereby the new SEZs and industrial parks will 'face the challenge that many similar attempts to construct special zones in African countries have failed'. ${ }^{99}$ As an integral aspect of China's formal Africa policies, the SEZs will be central to any evaluation of the claimed "win-win" relationship that is so prominent in official Chinese discourse vis-à-vis its ties with the continent. ${ }^{100}$ Equally, they will be no doubt useful indicators of Ethiopia's developmental progress

\footnotetext{
${ }^{99}$ Deborah Brautigam and Tang Xiayang, 2011, p. 49.

100 See Seifudein Adem 'China in Ethiopia: Diplomacy and Economics of Sino-Optimism', African Studies Review vol. 55, no. 1, 2012.
} 